\title{
The Evaluation of an Optical Method to Estimate Leaf Area of Grapevines
}

\author{
Junko Watanabe ${ }^{1}$, Robert M. Pool ${ }^{1}$ and Kazuo N. Watanabe ${ }^{2 *}$ \\ ${ }^{1}$ Department of Horticultural Sciences, Comell University, New York Agricultural Experimental Station, \\ Geneva, NY 14456 \\ ${ }^{2}$ Department of Plant Breeding and Biometry, Comell University, Ithaca, NY 14853-1902
}

\begin{abstract}
Summary
The ability of LAI 2000 Plant Canopy Analyzer to estimate the leaf area index (LAI) of grapevines canopies accurately was evaluated. This indirectly estimated LAI of grapevine canopies was compared to the directly measured (observed) LAI, using fully developed V. labrusca L. cultivar, 'Concord', canopies in 1993; In 1994, 'Concord' and 'Chardonnay' canopies at different growing stages were similarly analyzed.

Calibration was required to obtain reliable estimates of LAI because the growth habit of grapevines did not satisfy the requirement for random foliage distribution when applying gap fraction analysis. The most improtant consideration was sensor view field, which should be maximized when viewing randomly distributed canopies. Variables tested included reading postition, reading direction, view zenith angle and view opening angle.

It was easier to apply gap fraction analysis with a vigorous cultivar, 'Concord', because of its large canopy and more random foliage distribution than with 'Chardonnay'. For the latter, a typical $V$. vinifera grapevine, the view field needed to be narrowed because of its low vigor, pruning and training system, and non-random leaf distribution. Estimating leaf area in the middle or late season was easier than in early season when gaps between rows were large and foliage distribution was highly variable.
\end{abstract}

\section{Introduction}

Leaf area of canopy determines total light interception and influences the microclimate within it, which, in turn, affects the physiology, biochemistry, morphology, and yield of grapevines. Therefore, an accurate, indirect method to estimate leaf area of grapevine canopies would be useful to approximate the maximum production of quality fruits.

Common methodologies to estimate leaf area of plant canopies were well reviewed by Norman and Cambell (1991). The direct methods are accurate but time consuming, and many require destructive sampling. To estimate leaf area of grapevines, methods using linear leaf dimensions (Carbonneau, 1976; Elsner and Jubb, 1988; Manivel and Wea-

Received; May 15, 1996. Accepted; October 21, 1996.

*Corresponding author and present address:

Dept. Biotechnological Science, Faculty of Bioscience and Technology, Kinki University, 930 Nishi-Mitani, Uchita, Naga. Wakayama, 649-64, Japan ver, 1974; Schneider and Standt, 1981; Sepúlveda and Kliewer, 1983; Smith and Kliewer, 1984; William et al., 1958) and specific leaf area (Smith and Kliewer, 1984) have been applied. However, an indirect method is desirable to estimate the leaf area of perennial grapevines because of its large leaf area compared to canopies of annual crops.

Point quadrates, an indirect method, was used to characterize the micloclimate of grapevines rather than to estimate total leaf area by Smart and Robinson (1991). Gap fraction method offers a powerful tool for setimating leaf area index (LAI), leaf inclination angles for canopies of full cover, isolated single canopies, and even heterogeneous canopies (Norman and Cambell, 1991). Few studies have applied gap fraction methods for estimating leaf area of grapevines. The theory of gap fraction assumes that leaves are randomly and uniformly distributed within the canopy. These assumptions are rarely met in grape canopies under vineyard conditions because: 1) a large discontinuity between canopies attributed to planting 
in rows, 2) non-random distribution of leaf azimuth orientation, 3) impact of training system, 4) impact of pruning system, 5) the relatively large permanent structure, especially a trunk, and 6) the presence of trellis components.

LAI 2000 Plant Canopy Analyzer, which utilizes a gap fraction method estimating LAI using several fractional values of diffuse incident radiation that passes though a plant canopy (LI-COR, Inc., 1992) was tested by Grantz and Williams (1993) and Sommer and Lang, (1994) on different cultivars. Their levels of accuracy were satisfac tory, however, protocols used in these studies were different and the results were not applicable to the gap fraction method under different conditions.

To apply the gap fraction method for estimating grapevines leaf area, the selection of measuring conditions must be identified. This study aims to identify a protocol which maximizes the overall canopy view while minimizing leaf distribution bias. The view field can be controlled by adjusting: 1) places where under canopy readings are taken, 2) the directions of the field of view relative to the planting schemes, 3 ) view zenith angle, and 4) view restrictors (view opening). Data were further analyzed to optimize the view field under different conditions.

\section{Materials and Methods}

\section{1993 verification study}

\section{1) The determination of view postition}

The experiments were conducted on July 26 through July 30 in 1993 on V. labrusca L. cv. Concord in the commercial vineyard in Dresden, N. Y. The double trunked, own-rooted vines were planted in 1975. The row orientation is northsouth with $274 \mathrm{~cm}$ row spacing. Each vine was trained along two wires fixed at heights of $75 \mathrm{~cm}$ and $195 \mathrm{~cm}$, and spaced $244 \mathrm{~cm}$ apart. Three hand-pruned vines and three machine-hedged vines were randomly selected for this study. The vines for the hand-pruning treatment were cane-pruned to 30 nodes per vine. The other vines were hedged mechanically with vertical cuts of $7.6 \mathrm{~cm}$ by each side from the row center line. The pest management in the conventional managed vineyard followed New York and Pennsylvania Pest Management Recommendations (Weigle and Muza, 1993).
After estimating LAI, using LAI 2000 Plant Canopy Analyzer, approximately one third of the leaves were removed from each vine and the LAI of the defoliated portion was re-measured. This procedure was repeated until the vine was completely defoliated. All measurements at $45^{\circ}$ and $90^{\circ}$ view angles were taken at dusk or dawn. In Protocol 1 and 3 , ten readings were taken with the view oriented north. In Protocol 2, four readings were taken around each trunk (illustrated in Figure 1). The estimated and observed values of LAI from all cites were recorded using 1000-90 Communication Software (Ll-Cor, Lincoln, NE) and 2000-90 Support Software (Ll-Cor, Lincoln, NE).

About a hundred fresh leaves from each vine were randomly selected and their area was determined by leaf area analyzer. These subsampled leaves and the rest of leaves from each partially defoliated vines were dried separately at $49^{\circ} \mathrm{C}$ for four days. The specific leaf area (SLA, the leaf area per unit dry weight) was calculated from the dry weights of the subsamples and the total defoliated leaf area per defoliation stage was calculated using the SLA and total dry weight of leaves. Then the optically measured LAI was plotted against the observed or actual LAI. Regression analyses were performed by JMP (ASA Institute Inc., Cary, $\mathrm{NC}$ ).

2) The determination of view directions

To determine the effect of sensor orientation on the accuracy of the estimated LAI, readings were taken between rows along diagonal transects with a sensor oriented to east (Protocol 4, illustrated in Fig. 1). The result of Protocol 4 was compared to that of Protocol 1. The result of Protocol 2 was re-examined to determine the effect of sensor opening orientation. The defoliation and regression analyses were computed as above.

3) The determination of zenith view angle

Materials and methods were same as above; LAI was recalculated by using 2000-90 Support Software to eliminate readings at some zenith angles.

4) Calibrations of view restrictor angle

All materials and methods were same as above; the accuracies of estimated LAI between $45^{\circ}$ and $90^{\circ}$ view angles in Protocol 1,2 and 3 were com pared.

\section{1994 LAI comparison study}

Comparisons between the observed and esti- 


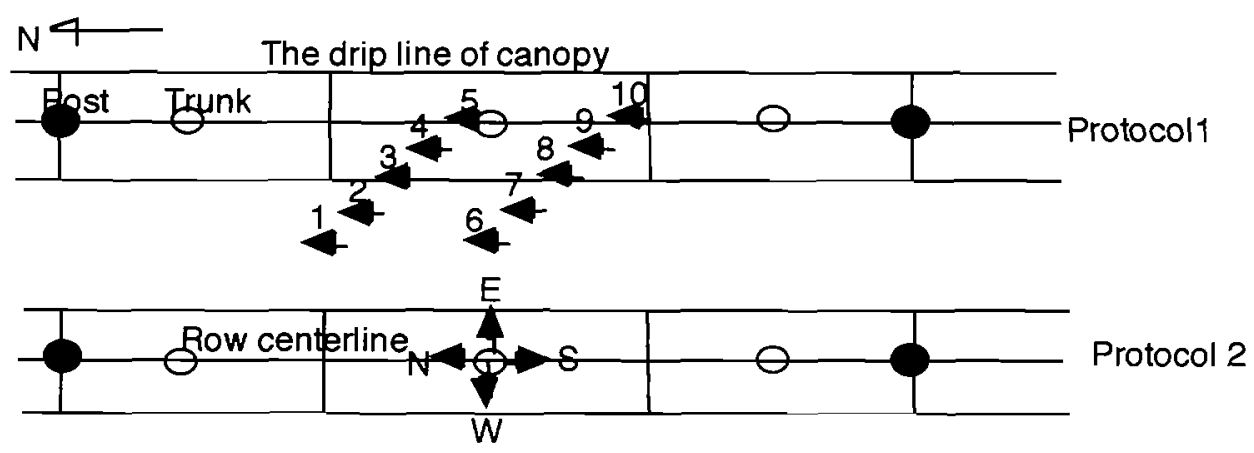

Empty space between rows
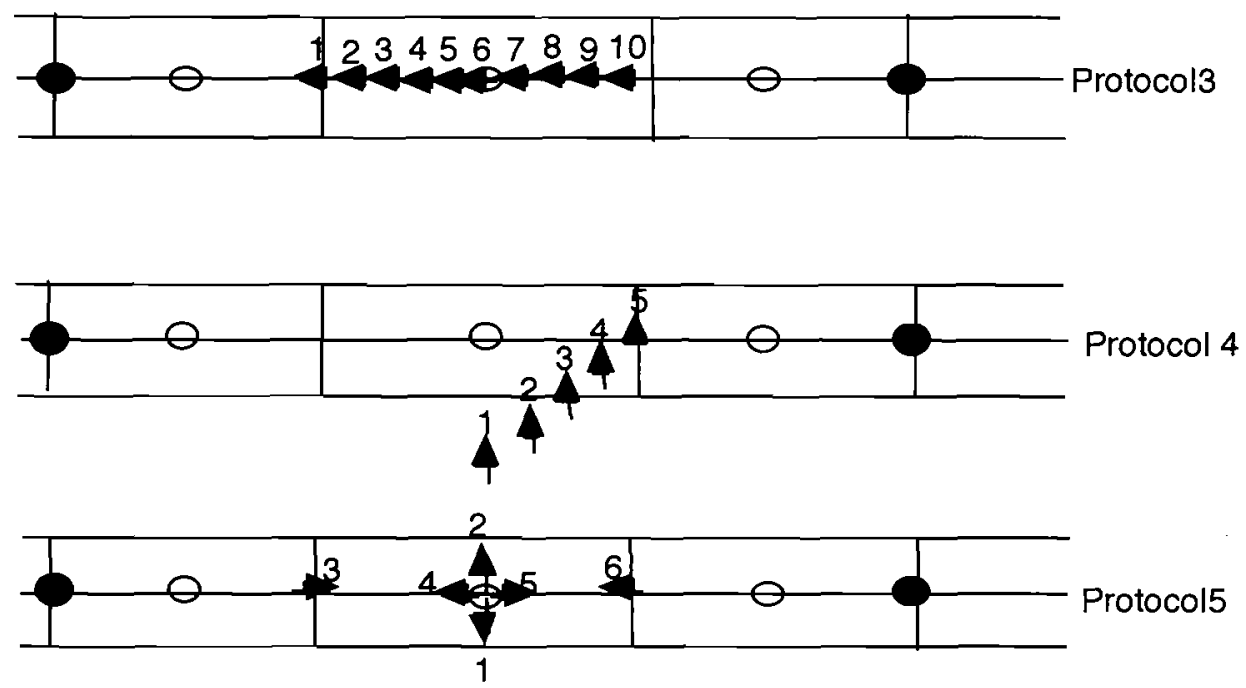

Fig. 1. The reading positions and directions of the sensor in Protocols 1, 2, 3, 4 and 5 Arrows indicate reading points and directions.

mated LAI were conducted on June 22 and 23 , July 7 and August 2 in 1994 on V. labrusca L. cv. Concord and $V$. vinifera L. cv. Chardonnay. Nineyear-old umbrella trained 'Concord' vines, planted in north-south oriented rows, receiving $20+20$ balance pruning growing in the Loomis blocks at the New York State Agricultural Experimental Station, Geneva, NY and fourteen-year-old Keuka High Renewal trained 'Chardonnay' vines growing in east-west oriented rows pruned and adjusted to 5 shoots on each of five canes in Vineyard 24 at NY State Agricultural Experimental Station, Geneva, NY were utilized. The pest management for these vines followed New York and Pennsylvania Pest Management Recommendations (Weigle and
Muza, 1993). Six vines were randomly selected from both cultivars.

The method of defoliation, the direct determination of leaf area, and the computer analysis in 1994 were the same as for the 1993 studies. Data for June were taken at dawn or dusk. The other measurements were taken under cloudy skies.

Readings were taken at six different locations under the canopy for all three comparative studies on 'Concord' and for the first study on 'Chardonnay'(Protocol 5). In Protocol 5, four readings around a trunk and two readings under the drip lines of the canopy were taken (Fig. 1). Two readings were made with the sensor positioned adjacent to the trunk and oriented toward the opposite 
ends of vines; two readings were made at right angle to the row and two readings were made with the sensor placed at the ends of the vines and facing the trunk. The angle of view was adjusted for $90^{\circ}$ with the $270^{\circ}$ view restrictor. Protocol 3 using the $45^{\circ}$ view angle was applied for the second and third dates with 'Chardonnay'.

\section{Results}

\section{The determination of view position}

Table 1 shows regression coefficients of determination and equations between estimated LAI $(x)$ and observed LAI (y) by different protocols. For Protocols 1, 2, and 3, the regression coefficient of determination of Protocol 2 was the highest $\left(\mathrm{R}^{2}=\right.$ 0.67 with $45^{\circ}$ view angle and $R^{2}=0.68$ with $90^{\circ}$ view angle). Protocols 1 and 3 with the $45^{\circ}$ view angle gave poor estimates of LAI.

When estimates from position in Protocol 1 were compared, readings at postition 10 were highly correlated with the observed LAI (Table 2), whereas reading at positions $1,2,3,4,6,7,8$, and 9 correlated poorly with the observed LAI. Thus, only view positions in the row center correlated with the actual LAI. Among the positions in Protocol 2 (Table 3 ), readings with the sensor oriented to the north or south produced better correlation than did the east-west orientations. Readings with the sensor oriented toward north had the highest regression coefficient, whereas those with the sensor oriented toward east had the lowest correlation for both $45^{\circ}$ and $90^{\circ}$ view angles. Regression values differed greatly among positions and view angle with Protocol 3 (Table 4). Positions 1-3 where the view of adjacent views is greater generally produced poor correlations. Positions 5 and $8-10$, which viewed the measured vine and not the trunks, produced better correlations. Generally, there was little difference between mid-vine positions (5 and 6) where the wider $90^{\circ}$ view gave markedly superior results. The values of the slope in linear regression equations approximate the tendency to over-or underestimates of the actual LAI. Protocol 1 underestimated LAI, whereas Protocol 2 and, especially, Protocol 3 overestimated it (Table 1).

After calculating regression coefficients for each reading position, several positions which were highly correlated with the observed LAI were combined and LAI was recalculated. The reading positions that were selected were those where the sensor was oriented north-south directions in Protocol 2 and the readings at postition 10 in Protocol 1 with the $90^{\circ}$ view angle. The regression coefficient between recalculated LAI from the two readings obtained in Protocol 2 (Combination 1) and the observed LAI was 0.78 and that between recalculated LAI from three readings (combination 2) and observed LAI was 0.86 (Table 1). Therefore, the combination of two readings with the sensor oriented, north-south in Protocol 2 and one reading at position 1 with the sensor oriented south and one at position 10 with sensor oriented north in Protocol 3 proved to be optimum for the 1994 study. These positions are illustrated in

Table 1. Regression equations and coefficients of determination between observed and estimated LAl using LAJ 2000 Plant Canopy Analyzer using different protocols and combinations.

\begin{tabular}{|c|c|c|c|c|c|}
\hline \multirow[b]{2}{*}{ View angle } & & \multicolumn{4}{|c|}{ Protocol } \\
\hline & & 1 & 2 & 3 & 4 \\
\hline $45^{\circ}$ & $\begin{array}{l}\text { Equation } \\
\mathrm{R}^{2}\end{array}$ & $\begin{array}{l}y=0.04+1.16 x \\
0.42\end{array}$ & $\begin{array}{l}y=-0.47+0.74 x \\
0.67\end{array}$ & $\begin{array}{l}y=0.007+0.38 x \\
0.49\end{array}$ & $\begin{array}{l}y=-0.55+0.81 x \\
0.77\end{array}$ \\
\hline \multirow[t]{2}{*}{$90^{\circ}$} & $\begin{array}{l}\text { Equation } \\
\mathrm{R}^{2}\end{array}$ & $\begin{array}{l}y=-0.75+2.11 x \\
0.60\end{array}$ & $\begin{array}{l}y=-0.55+0.98 x \\
0.68\end{array}$ & $\begin{array}{l}y=0.10+0.54 x \\
0.64\end{array}$ & $\begin{array}{l}\text { missing data } \\
\text { missing data }\end{array}$ \\
\hline & & \multicolumn{2}{|c|}{ Combination } & & \\
\hline View angle & & 1 & 2 & & \\
\hline $90^{\circ}$ & $\begin{array}{l}\text { Equation } \\
\mathrm{R}^{2}\end{array}$ & $\begin{array}{l}y=-0.69+0.86 x \\
0.78\end{array}$ & $\begin{array}{l}y=-0.67+0.89 x \\
0.86\end{array}$ & & \\
\hline
\end{tabular}


Table 2. Regression equations and coefficients of determination between observed and estimated LAl for each below canopy measuring point of Protocol 1 .

\begin{tabular}{|c|c|c|c|c|c|c|}
\hline \multirow[b]{2}{*}{ View angle } & & \multicolumn{5}{|c|}{ Point } \\
\hline & & 1 & 2 & 3 & 4 & 5 \\
\hline $45^{\circ}$ & $\begin{array}{l}\text { Equation } \\
\mathrm{R}^{2}\end{array}$ & $\begin{array}{l}y=0.95+0.62 x \\
0.01\end{array}$ & $\begin{array}{l}y=1.21-0.54 x \\
0.02\end{array}$ & $\begin{array}{l}y=1.04+0.12 x \\
0.00\end{array}$ & $\begin{array}{l}y=0.87+0.23 x \\
0.06\end{array}$ & $\begin{array}{l}y=0.18+0.35 x \\
0.44\end{array}$ \\
\hline \multirow[t]{2}{*}{$90^{\circ}$} & $\begin{array}{l}\text { Equation } \\
\mathrm{R}^{2}\end{array}$ & $\begin{array}{l}y=0.62+0.87 x \\
0.04\end{array}$ & $\begin{array}{l}y=0.90+0.36 x \\
0.01\end{array}$ & $\begin{array}{l}y=0.41+1.16 x \\
0.08\end{array}$ & $\begin{array}{l}y=0.59+0.60 x \\
0.10\end{array}$ & $\begin{array}{l}y=0.20+0.49 x \\
0.45\end{array}$ \\
\hline & & \multicolumn{5}{|c|}{ Point } \\
\hline View angle & & 6 & 7 & 8 & 9 & 10 \\
\hline $45^{\circ}$ & $\begin{array}{l}\text { Equation } \\
\mathrm{R}^{2}\end{array}$ & $\begin{array}{l}y=1.05+0.17 x \\
0.00\end{array}$ & $\begin{array}{l}y=1.40-1.40 x \\
0.05\end{array}$ & $\begin{array}{l}y=1.22-0.38 x \\
0.01\end{array}$ & $\begin{array}{l}y=0.71+0.34 x \\
0.13\end{array}$ & $\begin{array}{l}y=0.05+0.37 x \\
0.66\end{array}$ \\
\hline $90^{\circ}$ & $\begin{array}{l}\text { Equation } \\
\mathrm{R}^{2}\end{array}$ & $\begin{array}{l}y=0.71+0.72 x \\
0.05\end{array}$ & $\begin{array}{l}y=0.89+0.42 x \\
0.01\end{array}$ & $\begin{array}{l}y=0.11+1.74 x \\
0.18\end{array}$ & $\begin{array}{l}y=0.20+0.91 x \\
0.27\end{array}$ & $\begin{array}{l}y=-0.36+0.80 x \\
0.88\end{array}$ \\
\hline
\end{tabular}

Table 3. Regression equations and coefficients of determination between observed and estimated LAl obtained at each below canopy measuring point of Protocols 2 and 4.

\begin{tabular}{|c|c|c|c|c|c|c|}
\hline \multirow{2}{*}{$\begin{array}{c}\text { Protocl } 2 \\
\text { View angle }\end{array}$} & \multicolumn{6}{|c|}{ Point } \\
\hline & Point & North & East & South & West & \\
\hline $45^{\circ}$ & $\begin{array}{l}\text { Equation } \\
\mathrm{R}^{2}\end{array}$ & $\begin{array}{l}y=-0.02+0.42 x \\
0.67\end{array}$ & $\begin{array}{l}y=0.87+0.18 x \\
0.05\end{array}$ & $\begin{array}{l}y=-0.23+0.41 x \\
0.47\end{array}$ & $\begin{array}{l}y=0.67+0.53 x \\
0.28\end{array}$ & \\
\hline $90^{\circ}$ & $\begin{array}{l}\text { Equation } \\
\mathrm{R}^{2}\end{array}$ & $\begin{array}{l}y=-0.12+0.65 x \\
0.63\end{array}$ & $\begin{array}{l}y=0.55+0.35 x \\
0.09\end{array}$ & $\begin{array}{l}y=-0.34+0.63 x \\
0.53\end{array}$ & $\begin{array}{l}y=0.86+0.24 x \\
0.17\end{array}$ & \\
\hline Protocol 4 & & & & Point & & \\
\hline View angle & & 1 & 2 & 3 & 4 & 5 \\
\hline $45^{\circ}$ & $\begin{array}{l}\text { Equation } \\
\mathrm{R}^{2}\end{array}$ & $\begin{array}{l}y=-0.80+1.21 x \\
0.50\end{array}$ & $\begin{array}{l}y=-0.54+0.83 x \\
0.59\end{array}$ & $\begin{array}{l}y=0.37+0.63 x \\
0.68\end{array}$ & $\begin{array}{l}y=0.08+0.43 x \\
0.67\end{array}$ & $\begin{array}{l}y=0.08+0.53 x \\
0.53\end{array}$ \\
\hline
\end{tabular}

Fig. 1 .

\section{The determination of view directions}

Protocol 4 gave much better estimates of LAI $\left(R^{2}=0.77\right)$ than did Protocol $1\left(R^{2}=0.42\right)$ (Tables 1) because the reading positions in Protocol 4 were same as those in Protocol 1. In Protocol 4, the sensor opening was oriented within the row, whereas it was oriented toward the end of the row, viewing the empty row space between rows most of time. Among the sensor positions in Protocol 4, regression coefficient values were similar (Table 3). Reading with the sensor opening oriented to the north and south yielded better esti- mated LAI than did those with the sensor oriented to the east or west (Table 3). Comparisons between sensors oriented to the north or south showed that north readings gave better estimates of LAI.

\section{The determination of zenith view angle}

The effects of eliminating readings at the lowest $z$ enith angle on the estimated LAI were variable. There was no improvement by iliminating readings at the 5th zenith angle in Protocol 1, whereas masking it improved estimates of LAI in Protocols 2 and 3 (Tables 5 and 6). By masking the 5 th ring in Protocol 2 with the $90^{\circ}$ view angle, the regres- 
Table 4. Regression equations and coefficients of determination between observed and estimated LAl at each below canopy measuring point of Protocol 3.

\begin{tabular}{|c|c|c|c|c|c|c|}
\hline \multirow[b]{2}{*}{ View angle } & & \multicolumn{5}{|c|}{ Point } \\
\hline & & 1 & 2 & 3 & 4 & 5 \\
\hline $45^{\circ}$ & $\begin{array}{l}\text { Equation } \\
\mathrm{R}^{2}\end{array}$ & $\begin{array}{l}y=0.45+0.25 x \\
0.30\end{array}$ & $\begin{array}{l}y=0.38+0.27 x \\
0.32\end{array}$ & $\begin{array}{l}y=0.52+0.22 x \\
0.22\end{array}$ & $\begin{array}{l}y=0.34+0.29 x \\
0.38\end{array}$ & $\begin{array}{l}y=0.37+0.28 x \\
0.35\end{array}$ \\
\hline \multirow[t]{2}{*}{$90^{\circ}$} & $\begin{array}{l}\text { Equation } \\
\mathrm{R}^{2}\end{array}$ & $\begin{array}{l}y=0.61+0.25 x \\
0.23\end{array}$ & $\begin{array}{l}y=0.48+0.35 x \\
0.28\end{array}$ & $\begin{array}{l}y=0.23+0.50 x \\
0.46\end{array}$ & $\begin{array}{l}y=0.23+0.49 x \\
0.56\end{array}$ & $\begin{array}{l}y=0.21+0.50 x \\
0.64\end{array}$ \\
\hline & & \multicolumn{5}{|c|}{ Point } \\
\hline View angle & & 6 & 7 & 8 & 9 & 10 \\
\hline $45^{\circ}$ & $\begin{array}{l}\text { Equation } \\
\mathrm{R}^{2}\end{array}$ & $\begin{array}{l}y=0.19+0.34 x \\
0.52\end{array}$ & $\begin{array}{l}y=0.15+0.33 x \\
0.49\end{array}$ & $\begin{array}{l}y=-0.05+0.41 x \\
0.54\end{array}$ & $\begin{array}{l}y=0.33+0.28 x \\
0.41\end{array}$ & $\begin{array}{l}y=0.05+0.40 x \\
0.52\end{array}$ \\
\hline $90^{\circ}$ & $\begin{array}{l}\text { Equation } \\
\mathrm{R}^{2}\end{array}$ & $\begin{array}{l}y=0.11+0.53 x \\
0.71\end{array}$ & $\begin{array}{l}y=0.52+0.27 x \\
0.35\end{array}$ & $\begin{array}{l}y=0.17+0.52 x \\
0.59\end{array}$ & $\begin{array}{l}y=0.41+0.38 x \\
0.47\end{array}$ & $\begin{array}{l}y=0.48+0.31 x \\
0.50\end{array}$ \\
\hline
\end{tabular}

Table 5. Regression equations and coefficients of determination between observed and estimated LAl when data from various lower view rings were excluded.

\begin{tabular}{|c|c|c|c|c|c|c|c|}
\hline \multirow[b]{3}{*}{ Protocol } & & \multicolumn{6}{|c|}{ View rings excluded } \\
\hline & & \multicolumn{2}{|r|}{ None } & \multicolumn{2}{|c|}{ View angle ${ }^{5}$} & \multicolumn{2}{|c|}{$4+5$} \\
\hline & & $45^{\circ}$ & $90^{\circ}$ & $45^{\circ}$ & $90^{\circ}$ & $45^{\circ}$ & $90^{\circ}$ \\
\hline 1 & $\begin{array}{l}\text { Equation } \\
\mathrm{R}^{2}\end{array}$ & $\begin{array}{l}y=0.04+1.16 x \\
0.42\end{array}$ & $\begin{array}{l}y=-0.75+2.11 x \\
0.60\end{array}$ & $\begin{array}{l}y=0.24+1.13 x \\
0.41\end{array}$ & $\begin{array}{l}y=-0.04+1.86 x \\
0.52\end{array}$ & $\begin{array}{l}y=0.08+1.64 x \\
0.52\end{array}$ & $\begin{array}{l}y=-0.13+2.12 x \\
0.56\end{array}$ \\
\hline 2 & $\begin{array}{l}\text { Equation } \\
\mathrm{R}^{2}\end{array}$ & $\begin{array}{l}y=-0.47+0.74 x \\
0.67\end{array}$ & $\begin{array}{l}y=-0.55+0.98 x \\
0.68\end{array}$ & $\begin{array}{l}y=0.36+0.83 x \\
0.74\end{array}$ & $\begin{array}{l}y=-0.37+1.06 x \\
0.78\end{array}$ & $\begin{array}{l}y=-0.42+0.89 x \\
0.80\end{array}$ & $\begin{array}{l}y=0.05+0.78 x \\
0.78\end{array}$ \\
\hline 3 & $\begin{array}{l}\text { Equation } \\
\mathrm{R}^{2}\end{array}$ & $\begin{array}{l}y=0.007+0.38 x \\
0.49\end{array}$ & $\begin{array}{l}y=0.10+0.54 x \\
0.64\end{array}$ & $\begin{array}{l}y=0.04+0.41 x \\
0.55\end{array}$ & $\begin{array}{l}y=0.10+0.57 x \\
0.68\end{array}$ & $\begin{array}{l}y=-0.11+0.49 x \\
0.60\end{array}$ & $\begin{array}{l}y=0+0.61 x \\
0.74\end{array}$ \\
\hline
\end{tabular}

Table 6. Linear regression equations and coefficients of determination $\left(R^{2}\right)$ for 'Concord' and 'Chardonnay' LAl estimation models.

\begin{tabular}{clccc}
\hline \hline Cultivar & Date of study & Protocol & Regression equation & $\mathrm{R}^{2}$ \\
\hline Concord & June 22 and 23 & 5 & LAl $=-0.571+1.137$ (Indirect CAI) & 0.74 \\
& July 7 & 5 & LAl $=-0.239+0.713$ (Indirect CAI) & 0.74 \\
& August 2 & 5 & LAl $=-0.400+0.648$ (Indirect CAl) & 0.93 \\
& & & & \\
Chardonnay & June 22 and 23 & 5 & LAl $=0.213+0.316$ (Indirect CAl) & 0.08 \\
& July 7 & 3 & LAl $=-0.691+0.630$ (Indirect CAl) & 0.82 \\
& August 2 & 3 & LAl $=-0.288+0.475$ (Indirect CAl) & 0.80 \\
\hline
\end{tabular}

sion coefficients improved to $\mathrm{R}^{2}=0.78$. Eliminating the 5 th zenith angle narrowed the view field and increased the slopes of the regression equa- tions so that the overestimation of LAI in Protocols 2 and 3 was reduced. 


\section{Calibrations of view restrictor angle}

The readings with the wider view angle $\left(90^{\circ}\right)$ gave better LAI estimates than did those with the $45^{\circ}$ view angles in Protocols 1 and 3 (Table 1,2 and 4 ). With Protocol 2 , the estimate using the $45^{\circ}$ view angle gave a similar result to that using the $90^{\circ}$ view angle (Table 3 ). Overestimation was reduced by using the $90^{\circ}$ view angle rather than the $45^{\circ}$ view angle in Protocol 2 in which the slopes were 0.74 and 0.98 for the $45^{\circ}$ and $50^{\circ}$, respectively; the slopes were 0.38 and 0.54 for the $45^{\circ}$ and $90^{\circ}$, respectively, for Protocol 3 (Table 1). Underestimation of LAI increased using the $90^{\circ}$ view angle rather than the $45^{\circ}$ view angle in Protocol 1; the slopes were 1.16 and 2.11 for the $45^{\circ}$ and the $90^{\circ}$, respectively.

\section{1994 comparison study of LAI}

A linear regression analysis was carried out to obtain regression equations and coefficients of determinations (Table 6). Protocol 5 was appropriate for 'Concord' canopies because the coefficients of determination for linear fit were high, especially for the third study $\left(\mathrm{R}^{2}=0.93\right)$. With 'Concord', the first date gave a slight under-estimates of LAI (slope $=1.137$ ). As the canopy developed, the protocol provided over-estimates. It was found that Protocol 5 did not provide a reliable estimate of LAI for the 'Chardonnay' canopy (Table 6). The regression coefficient of determination was very low $\left(R^{2}=0.08\right)$. Therefore, the narrower field of view was used in Protocol 3 with late 'Chardon- nay' canopy trials. The view angle was narrowed to $45^{\circ}$ and was restricted to a position along the center of the row. Protocol 3 provided reasonably accurate estimates of LAI for the second and third measurements on 'Chardonnay' canopies. The regression coefficient for the third study did not improve from the second study. Because of the very narrow view of field, Leaf Area Index was severely over-estimated by Protocol 3 which used the $45^{\circ}$ view angle.

Masking the lower zenith angles improved the accuracy of the LAI estimates in 'Chardonnay' canopies in Protocol 5, but did not do so in 'Concord' canopies (Table 7). For both types of cano. pies, masking 2nd, $3 \mathrm{rd}$, 4th, and 5 th rings gave poor estimates of LAI. As more of the rings are masked, the larger were the overestimates attributable to the narrowing of the view field. Readings with the sensor opening oriented across the rows raised the accuracy of the estimated LAI in 'Concord' canopies, whereas no improvement was observed by adding such readings in the 'Chardonnay' canopies.

\section{Discussion}

Our results confirm the finding of previous investigators who found that the protocol recom. mended for row crops (Protocol 1), such as soybean, is inappropriate for grape canopies (Granz and Williams, 1993; Sommer and Lang, 1994). Readings taken in the empty space between rows are poorly correlated with the observed LAI (Table 2). The sensor probably does not monitor

Table 7. The effect of masking some zenith angles on regression equations and coefficients of determination between observed and estimated LAl.

\begin{tabular}{|c|c|c|c|c|c|c|}
\hline Cultivar & & All angles & Mask 5 & Mask 4,5 & Mask 3,4,5 & Mask $2,3,4,5$ \\
\hline Concord & $\begin{array}{l}\text { Equation } \\
\mathrm{R}^{2}\end{array}$ & $\begin{array}{l}y=0.57+1.14 x \\
0.74\end{array}$ & $\begin{array}{l}y=-0.34+0.85 x \\
0.68\end{array}$ & $\begin{array}{l}y=-0.35+0.60 x \\
0.73\end{array}$ & $\begin{array}{l}y=-0.34+0.37 x \\
0.74\end{array}$ & $\begin{array}{l}y=-0.09+0.19 x \\
0.21\end{array}$ \\
\hline Chardonnay & $\begin{array}{l}\text { Equation } \\
\mathrm{R}^{2}\end{array}$ & $\begin{array}{l}y=0.21+0.32 x \\
0.08\end{array}$ & $\begin{array}{l}y=0.09+0.33 x \\
0.14\end{array}$ & $\begin{array}{l}y=0.17+0.27 x \\
0.16\end{array}$ & $\begin{array}{l}y=0.13+0.17 x \\
0.19\end{array}$ & $\begin{array}{l}y=0.47-0.02 x \\
0\end{array}$ \\
\hline Cultivar & & \multicolumn{5}{|c|}{ No views of adjacen rows } \\
\hline Concord & $\begin{array}{l}\text { Equation } \\
\mathrm{R}^{2}\end{array}$ & $\begin{array}{l}y=-0.58+1.05 x \\
0.71\end{array}$ & & & & \\
\hline Chardonny & $\begin{array}{l}\text { Equation } \\
\mathrm{R}^{2}\end{array}$ & $\begin{array}{l}y=0.23+0.26 x \\
0.08\end{array}$ & & & & \\
\hline
\end{tabular}


any grape canopy at positions 1 or 2 . At positions 3 and 4 , the lens at low zenith angles obtained same image of vines, but those at high angle still view the empty space. Therefore, canopy discontinuity produced from wide row spacing resulted a large error of estimate. This also implies that much of the sunlight in vineyards is poorly intercepted, compared to that of annual close-planted crops.

Presence of structural vine parts, such as trunks, cordon arms, and trellis in the grape canopy contribute to the errors. When the sensor is oriented toward and held close to the objective, most of the lens may be occupied by the image resulting in over-estimation. Our result showed that readings obtained with the opening of the sensor oriented closely to trunks and posts correlated poorly with observed LAI. In other studies, the sensor was oriented away from the trunks (Sommer and Lang, 1994), or the orientation was not specified (Grantz and Williams, 1993). This consideration seems important especially when total leaf area of the canopy is small. However the error caused by trunks or posts may be small for dense canopies. The maximum LAI of 'Thompson Seedless' was approximately 5.5 (Grantz and Williams. 1993). For the annual crop canopy, such as soybean and corn, the area of stem compared to leaves is relatively small. For isolated trees, viewing away from the trunk is recommended (LI-COR, Inc., 1992). To minimize error caused by trunks and posts, the sensor should be faced away from them, especially when leaves are sparse in the early growing season, or/and the cultivars have a relatively small leaf area.

The result indicated that the effects of view direction on estimates of LAI are large. Even at the same viewing positions, a different direction monitored a different view field, especially when the view angle is small. If the readings are taken between rows, the sensor should be directed to the row and not to the end of the row. This result agrees with those of a previous study. There is no benefit from readings taken of open spaces between rows. When readings are taken between the rows, the view should be oriented toward the row at some appropriate distance from vines. In contrast, readings taken at positions too far, or too close to a row probably provide a view with less random foliage distribution.
View directions could have a large influence in estimating leaf areas when measurements are taken at dusk or dawn. The LI-COR LAI Analyzer manual does not provide any information about the measurements taken at sunrise or sunset, but light intensity seems very variable at these times of the day. When light intensity is too low, the difference in light intensity between above and below canopy readings are minimized and LAI is underestimated. The instrument operator needs to gain some knowledge on the critical light intensity to provide reliable LAI measurement for dawn and dusk recordings. Masking the three lower concentric sensors improved the estimated LAI for 'Thompson Seedless' canopies (Granz and Williams, 1993), because masking narrows the view of the adjacent open row spaces and the area of the maximum non-random leaf distribution.

The manual (LI-COR, Inc., 1992) suggested masking ring 5 when measuring vertically oriented: canopies, such as small grains. The leaf angle of grapevines appears to be randomly distributed. However, masking view rings greatly reduces the number of estimates of gap fraction which are obtained in any one readings. If only 3 rings were used, the LAI measured between rows with masking are close to zero. Therefore there is no advantage to obtain readings in the space between rows.

Improvement of estimated LAI by masking lowest zenith angle could result from reduction of the reflected direct sun light or by minimizing the view of non-random foliage. Because the measurements were taken at sunset, lower zenith rings were most likely to be affected by direct light. It was assumed that eliminating the 5 th rings would improve the accuracy of estimation in Protocol 1 by minimizing the effect of non-random foliage at the margin between empty space and the canopy. It is not clear whether the improved estimates were the effect of eliminating direct sunlight or random foliage view.

The area of the field of view should be carefully chosen by understanding the degree of randomness of leaf distribution. For best estimates of LAI, the target field of view should be maximized. After the area with relatively random leaf distribution is determined, the largest field of view should be selected. Narrower view requires more calibration. For example, the view of field by Protocol 2 with 
the $90^{\circ}$ view angle with a canopy height of approximately $2 \mathrm{~m}$ is $12.6 \mathrm{~m}^{2}$, which is $88 \%$ more than the ground area occupied by the grapevine $(6.7$ $\mathrm{m}^{2}$ ). On the other hand, with Protocol 2 and the $45^{\circ}$ view angle, the total field of view is $6.3 \mathrm{~m}^{2}$ or approximately $94 \%$ of vine ground area. When view positions are concentrated in the center line of the row, LAI will theoretically be overestimated.

Our results indicate that $90^{\circ}$ view angle is more appropriate than $45^{\circ}$ view angle for estimating LAI of 'Concord' canopies. However, using a wider view angle at an empty space between rows increased the possibility of error. The wider view angle is especially appropriate for large, wide canopies, such as 'Concord' canopies, or for lightly pruned canopies. However, for narrow canopies, the $45^{\circ}$ view angle might be more appropriate. The determination of view angle for canopies with narrow canopies will be discussed later. In the early growing season, most leaf area is concentrated along canes and spurs. As the season progresses and shoots elongate, leaf distribution tends to be more random. Therefore estimations are probably more reliable later in the season than during early or mid-season. Results with 'Concord' canopies showed that highest regression coefficient of determination was obtained in August. However, no improvement of regression coefficient was observed between the second and the third observation on 'Chardonnay'. This difference might be attributed to the different patterns of vegetative growth between these two cultivars. Estimate of LAI in the early season could be improved by utilizing a very narrow field of view along canes, arms and spurs.

The pruning and training systems also contribute to the violation of the assumption of random foliage distribution. For example, most of the leaves are distributed above the wire with 'Chardonnay' canopies where canes are tied to trellis wires. Shoot growth of 'Chardonnay' also tends to be upright, creating non-random foliage distribution. In 'Concord' canopies, leaves tend to be distributed along the canes in the early season, but by mid season, 'Concord' vines grow more or less randomly into the space between rows. The estimation of leaf area in the training and pruning systems in which leaf distribution is even more random should be more reliable. Machine hedged or minimally pruned grapevines produce this type of canopy. The estimate of LAI in minimally pruned 'Cabernet Sauvignon' was accurate with gap fraction methods using LAI 2000 Plant Canopy Analyzer and Demon (CSIRO, Division of Environmental Mechanics, Canberra, Australia) in Australia (Sommer and Lang, 1994).

Vertically trained, severely pruned or low vigor vines require several adjustments of the technique to obtain good estimates of LAI by LAI 2000 Plant Canopy Analyzer. Vertically oriented $V$. vinifera grapes, as typically grown in New York, are in this category. For this type of canopy, the field of view should be adjusted by restricting the view as much as possible to the area of relatively random leaf distribution. In the first verfication study on 'Chardonnay', the $90^{\circ}$ view angle measured the area of the margin between canopies and the space between rows, where leaf distribution was severely biased. When the field of view was narrowed for the second and third studies to the $45^{\circ}$ view angle, improved estimates were obtained. Further more, by restricting the view to only the area directly under the center line of rows, better results were obtained with 'Chardonnay' canopies.

\section{Acknowledgments}

We acknowledge helpful advice and assistance from Dr. K. J. Sommer. We thank Drs. L. L. Creasy and P. M. Ludford for reviewing the manuscript and helpful comments. This research was funded in part by a grant from New York Grape and Wine Foundation.

\section{Literature Cited}

Carbonneau, A. 1976. Principes et méthodes de mesure de la surface foliaire: Essat de caractérisation des types de feuilles dans le genre Vitis. Ann. Amélior. Plantes. $2: 327-343$.

Elsner, E. A. and G. J. Jubb. 1988. Leaf area estimation of Concord grape leaves from simple liner measurements. Am. J. Enol. Vitic. 39 : 95-97.

Grantz, D. A. and L. E. Williams. 1993. An empirical protocol for indirect measurement of leaf area index in grape (Vitis vinifera L.). HortScience 28 : 777-779.

LI-COR, Inc. 1992. LAI-2000 Plant Canopy Analyzer operating manual. LI-COR, Inc., Lincoln, Nebraska.

Manivel, L. and R. J. Weaver. 1974. Biometric correlation between leaf area and length measurements of 'Granache' grape leaves. HortScience 9:27-28.

Norman, J. M. and G. S. Campbell. 1991. Canopy struc- 
ture. p. 301-325. In: R. W. Pearcy, J. Ehleringer, H. A. Mooney and P. W. Rundel (eds.). Plant physiological ecology. Chapman and Hall, UK.

Schneider, W. and G. Standt. 1981. A simple method for determining grapevine leaf area. Mitt. Kloster. neuburg $31: 186-189$.

Sepúlveda, G. R. and W. M. Kliewer. 1983. Estimation of leaf area of two grapevine cultivars (Vitis viniifera L.) using laminae liner measurements and fresh weight. Am. J. Enol. Vitis. 34 : 221-226.

Smart, R. E. and M. Robinson. 1991. Sunlight into wine: A handbook for winegrape canopy management. Winetitles, New Zealand.

Smith, R. J. and W. M. Kliewer. 1984. Estimation of
Thompson Seedless grapevine leaf area. Am. J. Enol. Vitis. $35: 16-22$.

Sommer, K. J and A. R. G. Lang. 1994. Comparative analysis of two indirect methods of measuring leaf area index as applied to minimal and spur pruned grape vines. Aust. J. Plant Physiol. 21 : 197-206.

Weigle, T. H. and A. J. Muza. 1993. New York and Pennsylvania pest management recommendations for grapes. Cornell Cooperative Extension, Cornell University, Ithaca, N. Y.

William, B. A., P. C. Crandall and T. S. Russell. 1958. The use of liner measurements in estimating leaf areas. Proc. Amer. Soc. Hort. Sci. 72 : 326-330.

\title{
ブドウ樹の葉面積測定のための光学的方法の評価
}

\author{
渡辺純子 ${ }^{1} \cdot$ Robert M. Pool ${ }^{1} \cdot$ 渡辺和男 $^{2 *}$ \\ ${ }^{1}$ Department of Horticultural Sciences, Comell University, New York Agricultural Experimental Station,
}

Geneva, NY 14456

${ }^{2}$ Departmen ot Plant Breeding and Biometry, Comell University, Ithaca, NY 14853-1902

\begin{abstract}
摘要
LAI 2000 PLANT CANOPY ANALYZER 用い, 光学的にブドウ樹の葉面積指数（Leaf Area Index, LAI）を測定し，これを間接的な葉面積測定方法とし て評価を行い，直接的な方法で測定したLAI 檤と比 較した。1993 年度の研究には，最大限に伸長した 'Concord' (V. labrusca) を, 1994 年度には, 'Concord’および'Chardonnay' (V. vinifera) を供試し，し かも異なった生長過程で測定の比較を行った.

ブドウ樹の樹冠は，ギャップフラクション分析を適 応する際，葉が無作為に分布するとする仮定に適合し ないことがあり，光学的方法を用いた測定には調節が 不可欠であった，最も重要なことはレンズの視野の調 節であり，葉が無作為に分布している際には，レンズ の視野は最大限に搪張する方が正確であった，測定場

所，測定の方向と方角，また、レンズの視野の広さの 及ほす正確さへの影響も同時に調べられた。

アメリカ種の 'Concord’ では, 生育旺盛で樹冠の葉 がより無作為に分布するため，ギャップフラクション 分析を適応させることが容易であった。これとは逆に， ヨーロッパ種の代表品種である 'Chardonnay'は, 生 育虚弱で，また，毎年行われる強せん定の影锌が大き く，葉の分布が非常に偏っており，レンズの視野がよ り限定されなければならないことがわかったままた， 生長期の早い時期は，樹冠が小さく，そのため畧間に 存在する広範囲なすきまのため，葉の分布が非常に偏 っており，生長の中期または，後期よりも，光学的方 法を用いた葉面積の正磪な測定がむずかしいことがわ かった。
\end{abstract}

\footnotetext{
*現在：近畿大学生物理工学部
} 